\title{
通信を利用した船上における食習慣問診の試みと事例検討
}

\author{
福田 直子 ${ }^{1} \cdot$ 亀山 こころ $・$ 庄司るり ${ }^{3} \cdot$ 芦田研二 ${ }^{4}$

\section{The Electronic Health Interview Questionnaire for Eating Habits on Board and Case Assessment}

\author{
Naoko FUKUDA, Kokoro KAMEYAMA, Ruri SHOJI and Kenji ASHIDA
}

\begin{abstract}
The present study developed the health monitoring system including an electric interview for seafarers boarding on a coastal vessel with mobile phone communication. Nineteen male seafarers were monitored health-related information for about three months. They measured blood pressure, body weight and step counts per a day and inputted their life histories to a personal computer (PC) on board once a day. These data were recorded by the PC on board and when the ship was within cellphone coverage area, the PC uploaded the data to the server on land. Compare to the lifestyle on the land which was examined previously with self-administered questionnaires, overeating was controlled, however, skipping a meal and snacking was not changed on board. Drinking and smoking habits were not changed between on board and land. Among twelve obese seafarers, eleven seafarers were drinkers and five drinkers had habits of overeating, skipping a meal, and snacking in addition. The health interview questionnaire of seafarers on board with mobile phone communication was successful. Also, the lifestyle habits obtained by the interview were indicated to be useful for the health assessment and the guidance of individual seafarers.
\end{abstract}

Keywords: Labor conditions, Telemedicine, Lifestyle habits, Seafarer, Health management キーワード: 労働環境, 遠隔医療, 生活習慣, 船員, 健康管理

\section{1.はじめに}

生活習慣病は生活習慣が病気の発症や進行に関 与している疾患と定義されている。船上と陸上の 2 つの生活を繰り返寸船員においては、2つの生活の 関与を考えていく必要がある。特に船上は、職住一 体の長い時間を過ごす場であることから、そこでの 生活習慣は船員の健康に大きな影響を与えている可 能性がある。船上において、生活習慣改善を可能と し、健康的な生活を送れるようにすることは、船員 の生活習慣病を予防し、さらには船員の労働環境改
善にも寄与寸るものと考えられる。

しかし船内は健康的な生活習慣を継続する上で、 様々な強い制約のある不利な環境である。食事とし ては、規定量に基づく食材が使用され、一律の給食 が提供されるので、個人の活動量や健康状態にあわ せることは難しい(1)。空間が限られているため運動 を行いにくい(2)。当直や荷役などで睡眠や休養を十 分にとりにくい (3)。閉鎖空間ゆえの娛楽の少なさか らか飲酒や喫煙が習慣化しやすい ${ }^{(3)}$ 。実際に、内航 船船員の船内生活のアンケート調查でも、「定期的な

\footnotetext{
1 正会員 東京海洋大学保健管理センター

2 正会員 華学園栄養専門学校

3 正会員 東京海洋大学大学院海洋工学系

4 非会員 日本無線株式会社
} 


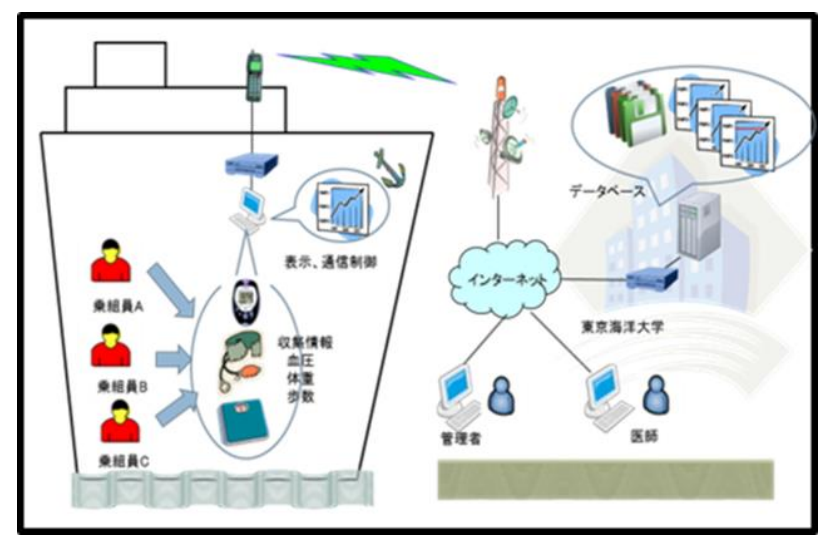

図 1 船舶遠隔健康管理システムの概要

運動」、「7〜8 時間の睡眠」「喫煙しない」「お酒は 毎日飲まない」などの健康習慣の実施率は低かった と報告されている(4)。

筆者らは、船上船員の健康的な生活を支援する仕 組みとして、以前より通信を利用した船舶遠隔健康 管理を提案してきた ${ }^{(5)}$ 。開発したシステムを使用し 実験も行った。東京海洋大学練習船乗組員の協力を 得て、船内で体重（後に船のゆれのためデジタル体 重計で量れないことが判明)、血圧、体温などの自己 計測と計測值のパーソナルコンピュター (以下、PC) への入力、さらに生活習慣などの問診票への記入を 試行してもらった。衛星通信を介して陸上からデー 夕を照会することができるようにした。

この実験により、乗組員に負担感をあまり与える ことなく、実施できることが確認されたが、3 日間 で東京湾近海を航海する船での実験であったため、 長期に運航している船で船舶遠隔健康管理システム が運用可能かどうかは不明であった。

今回、あらためて船舶遠隔健康管理システムを構 築し、遠隔で内航船船員の生活習慣を含む健康情報 をモニタリングする試行を行い、得られた情報から 内航船船員の船上の生活習慣の傾向を分析、あわせ て、問診項目の内容の適切さを検討した。加えて、 船上での保健指導に有用な知見を得るため、肥満事 例について検討を行った。

\section{2. 方法}

\section{1 船舶遠隔健康管理システムの概略}

船上で血圧、体重、歩数および生活習慣に関する 問診を記録してもらい、陸上で確認する遠隔船舶健 康管理システムを構築した (図 1)。船上での手順は、 1 日 1 回、専用 PC にパスワードを入力して個人画面 を開き、体重と血圧を計測・登録、歩数計をアダプ
タに接続、問診入力である。体重、血圧のデータは 計測後自動で、歩数は歩数計を専用アダプタにセッ トすることで、Bluetooth 経由で船内専用 PC に転送 される。歩数計は最大 30 日分の值を記録でき、毎回 アダプタにセットする必要はない。生活習慣に関す る問診は、専用 PC 上の選択肢メニューを使い入力す る。被験者は自分のデータを折れ線グラフ等で見る ことができる。

専用 PC 上のデータは、船陸間通信可能時に東京 海洋大学構内にある船舶健康管理サーバに転送・記 録される。対象船舶に既搭載の携帯電話通信を船陸 間通信として利用した。計測機器・専用 PC は船橋に 設置した。

\section{2 対象と実践}

対象船舶は東北地方から中国地方までの本州を 航行する内航航路商船（セメント運搬船、約 20000 トン）である。2〜 5 日に 1 度以上、寄港地としてあ らかじめ決められている港に接岸し荷役を行う。乗 組員は 3 か月航海し、1 か月を陸上で過ごす。航海 中は 1 か月に 3 日の休みがあるが休みを取れないこ とも多い。航海士など当直勤務を行う者と日勤者の 異なる勤務形態がある。船内生活における食事は朝 食、昼食、夕食が決まった時間に供され、米飯のお かわりは自由で、間食・夜食は供されない。

船員に研究協力を依頼する際、研究の目的と実施 内容を説明し、協力は自由意思であること、不参加 で不利益を受けないこと、途中で止めてもいいこと、 情報は研究発表等で公表することがあるが匿名性は 維持することなどを説明し、同意書の得られた者の み参加してもらった。実施期間は 2012 年 7 月下旬か ら約 3 か月間で、協力者は 19 人 (すべて男性) であ った。年齢構成は 20 歳代 7 人、30 歳代 1 人、40 歳 代 3 人、50 歳代 8 人であった。なお 30 歳代は 1 人 のみであるため、年代別平均からは除外している。 職種は船長 2 人 (ともに 50 歳代)、甲板部職員 6 人 (20 歳代 2 人、40 歳代 2 人、50 歳代 2 人) 、甲板部 部員 5 人 (20 歳代 2 人、 40 歳代 1 人、 50 歳代 2 人)、 機関部職員 5 人 $(20$ 歳代 3 人, 50 歳代 2 人)である。

協力者には実施開始前には陸上生活習慣に関す る記名式アンケート調查を、終了後にはシステム評 価に関する無記名式アンケート調查を実施した。

\section{3. 結果}

\section{1 船上の計測值}


表 1 乗組員の年代別計測值と国民健康栄養調査（2011 年）の比較

\begin{tabular}{|c|c|c|c|c|c|c|c|c|}
\hline & \multicolumn{4}{|c|}{ 乗組員 } & \multicolumn{3}{|c|}{ 国民健康栄養調査(2011年) } \\
\hline & & 全体 & 20歳代 & 40歳代 & 50歳代 & 20歳代 & 40歳代 & 50歳代 \\
\hline 歩数 & （歩/日） & $6613 \pm 2833$ & $7947 \pm 2382$ & $7517 \pm 4802$ & $5246 \pm 2132$ & $8199 \pm 5151$ & $8090 \pm 4571$ & $7693 \pm 4978$ \\
\hline 体重 & $(\mathrm{kg})$ & $77.9 \pm 16.0$ & $77.2 \pm 12.7$ & $70.8 \pm 8.45$ & $74.7 \pm 8.57$ & $66.5 \pm 12.9$ & $69.6 \pm 11.3$ & $68.5 \pm 10.9$ \\
\hline BMI & $\left(\mathrm{kg} / \mathrm{m}^{2}\right)$ & $26.61 \pm 5.06$ & $25.93 \pm 4.58$ & $23.75 \pm 2.24$ & $25.93 \pm 2.97$ & $22.66 \pm 3.94$ & $24.16 \pm 3.67$ & $23.99 \pm 3.29$ \\
\hline 最高血圧 & $(\mathrm{mmHg})$ & $128.6 \pm 11.6$ & $123.8 \pm 10.9$ & $135.8 \pm 14.2$ & $129.1 \pm 11.1$ & $119.6 \pm 12.2$ & $126.4 \pm 18.8$ & $134.8 \pm 17.3$ \\
\hline 最低血圧 & $(\mathrm{mmHg})$ & $81.2 \pm 9.26$ & $74.1 \pm 7.10$ & $87.3 \pm 5.13$ & $84.8 \pm 9.35$ & $74.3 \pm 10.1$ & $82.4 \pm 12.4$ & $85.8 \pm 10.9$ \\
\hline
\end{tabular}

平均土標準偏差

起床後朝食前計測を依頼したが、継続的に測定し てもらうため、仕事の都合上の変更も認めることと した。被験者全体の計測日総数は、歩数が 970 日、 血圧が 732 日、体重が 647 日であった。船のゆれの ためデジタル体重計が安定しない場合、体重は測定 しないこととした。表 1 に、歩数、Body Mass Index（以 下、BMI)および血圧の全体平均を示した。なお BMI は体格指数 $[$ 体重 $(\mathrm{kg}) /\{$ 身長 $(\mathrm{m}) \times$ 身長 $(\mathrm{m})\}]$ である。 歩数は $6756 \pm 2844$ 歩 (平均土標準偏差、以下同様) で、 20 歳代、 40 歳代が 50 歳代に比べて多かった。 職種によっても差が見られ、甲板部部員 $(7667 \pm 3959$

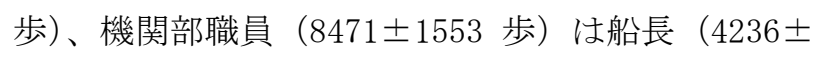
475 歩)、甲板部職員 $(4119 \pm 526$ 歩 $)$ より多かった。

BMI は 25 以上で肥満域と判定される。全体平均は $25.61 \pm 3.52$ と肥満域で、 20 歳代と 50 歳代の平均も 25 以上だった。個人平均が 25 以上だった者は 12 人 で、20 歳代が 4 人 (20 歳代の $57.1 \%) 、 30$ 歳代の 1 人、40 歳代が 1 人 (40 歳代の $33.3 \%) 、 50$ 歳代が 5 人 $(50$ 歳代の $62.5 \%)$ であった。

表 1 に 2011 年国民健康栄養調査 ${ }^{(6)}$ の同年代の男 性平均も示した。比較すると、歩数はどの年代も国 民健康栄養調查よりも少ない傾向で、特に 50 歳代で 差が大きかった。体重、BMI は船員の方が大きかっ た。血圧については、40 歳代の船員の最高血圧、最 低血圧ともに国民健康栄養調査より高めだったが、 国民健康栄養調査では熟練者による 2 回測定の平均 值であるため単純に比較できない。以上、船上での 計測では、国民の同年代の男性より歩数が少なく体 重が重いという傾向が見られた。

\section{2 船上の生活習慣}

問診では記録する日の前日の状態を尋ねた（表 2)。 勤務の合間に負担なく記録できるよう、項目数と内 容に配慮した。食に関する問診はエネルギー摂取に 関する質問事項とした。その際、肥満者生活状況調 查 ${ }^{(7)}$ の結果を参考に、肥満の要因であった “食事量 過多”、“間食・夜食”、“朝食を摂ったり取らなかっ たり”の内容を取り入れた。飲酒は適正飲酒 ${ }^{(8)}$ と されている日本酒 1 合相当（エタノール換算 $20 \mathrm{~g} / \mathrm{day}$ 程度）とした。生活習慣の記録日総数は 686 日だった。

全被験者の記録日数中の各回答の割合を図 2 に示 した。食事はおおむ称 3 食摂っていたが、「3 食 (量 : 多め)」（以下、過食）が 11\%に見られ、久食は $12 \%$

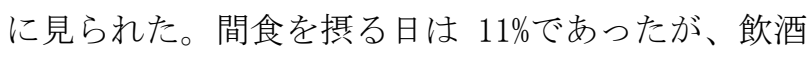
をする日は $74 \%$ と多かった。睡眠時間は 4 時間未満 が $11 \%$ 見られ、「寝つきが悪い」「夜中に目が覚め る、あるいは眠れない」（以下、不眠）日も $43 \%$ 見ら れた。年代別不眠の割合は、50 歳代が $66.5 \%$ 、40 歳 代が $19.7 \%$ 、20 歳代が $12.1 \%$ と 50 歳代に多かった。 個別に見ると、偏った生活習慣は特定の人に見ら れた。過食は 3 人 (対象者の $15.8 \%$ )、久食は 5 人 (同 $26.3 \%$ )、間食は 8 人 (同 $42.1 \%$ )、飲酒は 15 人 (同 $78.9 \%$ )、喫煙は 9 人（同 $47.3 \%)$ に見られた。 それらの者における各生活習慣の発生頻度は以下の 通りであった。過食者 3 人の過食頻度は $43.3 \%$ 、欠 食者 5 人の欠食頻度は $49.0 \%$ 、間食者 8 人の間食頻 度は $24.4 \%$ 、飲酒者 15 人の飲酒頻度は $91.4 \%$ 、喫煙 者 9 人の喫煙頻度は $99.0 \%$ あった。睡眠時間が 4

表 2 問診項目と選択肢

\begin{tabular}{|c|c|c|}
\hline 問診項目 & 選択肢 & \\
\hline 1. 前日の食事 & 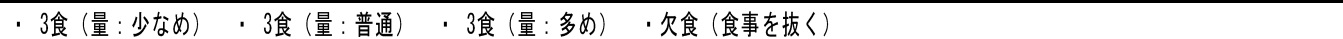 & \\
\hline $\begin{array}{l}\text { 2. 前日の間食 } \\
\text { （夜食を含む） }\end{array}$ & ・あり・なし & \\
\hline 3. 前日の飲酒 & ·日本酒1合相当未満（清酒なら1合未満、ビールなら500m|未満、焼酎20度なら135m|未満、ウィスキーならダブル1杯未満、ワインなら2 杯未満） & ·それ以上 \\
\hline 4. 前日の喫煙 & ·なし $\cdot 5$ 本以下 $\cdot$ 10本以下 $\cdot 20$ 本以下 $\cdot 21$ 本以上 & \\
\hline 5. 前日の睡眠時間 & · 4時間未満 · 4 6時間 · 6 8時間 · 8時間以上 & \\
\hline 6. 前日の睡眠 & ・よく眠れる·寝つきが悪い，夜中に目が覚める、あるいは眠れない & \\
\hline
\end{tabular}



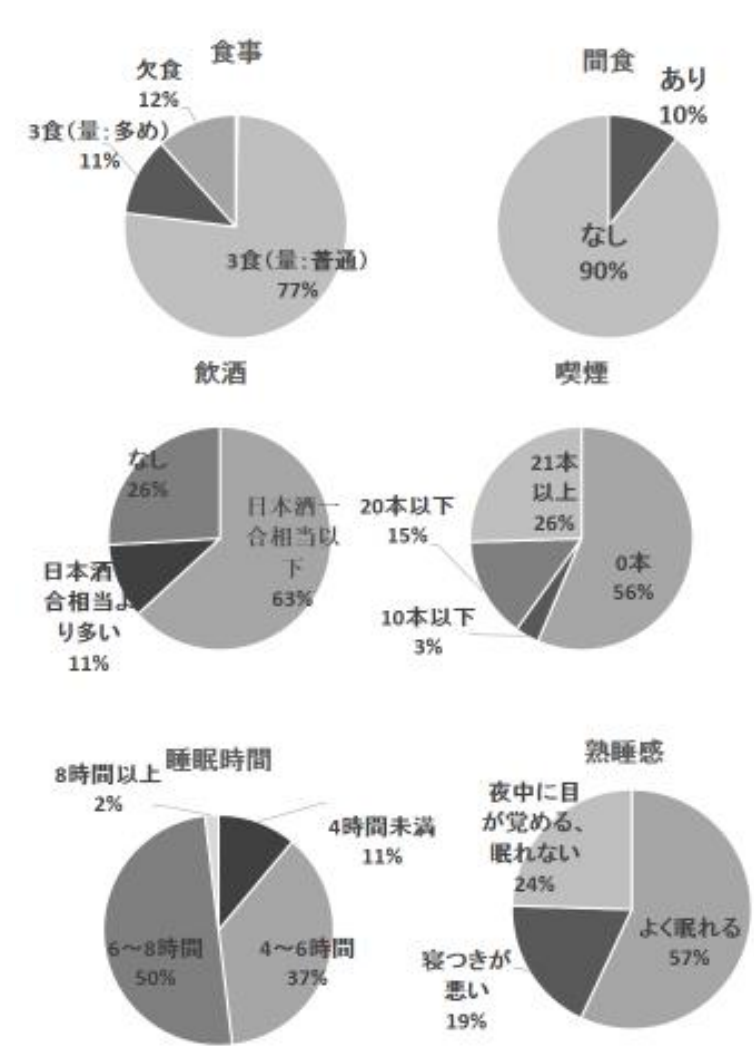

図 2 船上の生活習慣（食事、間食、飲 酒、喫煙、睡眠時間、睡眠の質) の日の割合

時間未満は 10 人に見られた。そのうち 7 人が甲板員、 2 人が機関員、 1 人が船長であった。不眠が記録の過 半数の者は 8 人で、そのうち 5 人が 50 歳代であった。

\section{3 陸上の生活習慣との比較}

研究実施前、陸上での生活習慣のアンケート調査 を行い、16 人から回収した。過食、欠食、間食、飲 酒、喫煙、不眠について頻度を問い、それらの生活 習慣が 1 週間あたりまったくない場合は「なし」、1 度以上ある場合には「ときどき」、ほぼ毎日ある場合 には「毎日」と分類した。

船上の生活習慣の分類においては、概ね連続的に 記録している者では同じ方法で、散発的に記録して いる者は記録日数中の各生活習慣の記録日の割合を 算出して次のようにした。7日に 1 日の割合の $14.3 \%$ 以上を「ときどき」、7 日に 6 日の割合の $85.7 \%$ より 大きいものを「毎日」とした。図 3 に陸上と船上で 生活習慣の比較を示した。なお陸上生活習慣のアン ケート調査で回答未記入があったため、各生活習慣 の総人数は 16 人とは限らない。

陸上と船上において各生活習慣の頻度に違いが あったため、符号検定を行った。符号検定とは対応

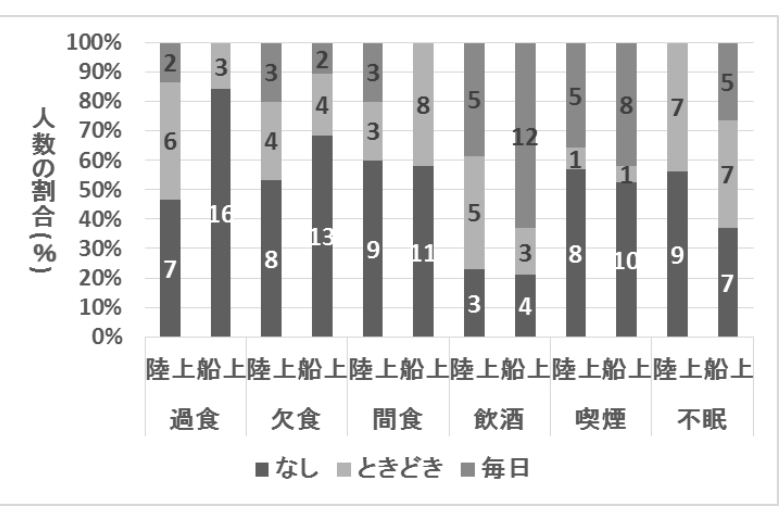

図 3 船上と陸上の生活習慣の比較 (グラフ内の数字は人数)

のある $2 つ の$ 標本について差があるかどうかを見る 検定法である。対応寸る 2 変数は大小 (または優劣) しかわからないとき、寸なわち順序データのときに 適用し、2 標本の中央値に差がないか検定する。統 計ソフトは IBM SPSS Statistics 20 を用い、有意水 準は $5 \%$ とした。分析の結果、過食が $p=0.016$ で有意 な差が見られたが、他の生活習慣に差は見られなか った。陸上に比べ船上では過食が減じることが示さ れた。

統計的な差は無かったが、個別に見ると、陸上で 欠食習慣のあった 7 人中 4 人が船上では欠食習慣が なくなり、間食習慣のあった 6 人中 4 人が船上では 間食習慣が減じるという変化があった。一方、飲酒、 喫煙は、個別に見ても、陸上と船上で頻度や量が変 わった者はなかった。睡眠については、陸上でほぼ 毎日熟睡している者が 9 人いたが、その中 3 の人は 船上ではほぼ毎日不眠、1人は週に 1 日程度しか熟 睡できなくなった。睡眠時間は、全員が陸上で 5 時 間以上の時間を回答したが、船上では 10 人に 4 時間 未満が見られ、睡眠の量・質ともの減少が示唆され た。

また陸上の生活習慣のアンケートで運動に関す る意識も調査した。運動を習慣化している者はいな かった。実行しているが習慣化はしていない」との 回答が 4 人、「実行に努力はしているが十分でない」 との回答が 5 人、「実行していないが実行しょうと考 えている」との回答が 2 人、「実行しょうと考えても いない」との回答が 3 人であった。

\section{4 肥満者の個別検討}

被験者に多く見られた肥満は、糖尿病、高血圧、 脂質異常症、心血管病、慢性腎臓病など生活習慣病 全般のリスクファクターである。船員は陸上労働者 
に比べて肥満が多いとの報告もある ${ }^{(9)}(10)$ 。乗組員 の肥満者の船上生活習慣を検討し保健指導のヒント を探ることは船員の生活習慣病予防を考える上で重 要と考えられる。

そこで、栄養指導に活かせるよう肥満者 12 人の 船上での食・飲酒習慣を整理しタイプ分けを行った

(表 3)。飲酒習慣がある者が 12 人中 11 人 (91.7\%) と多かったため、飲酒習慣の有無を中心として、(1) 飲酒習慣と食の過不足があるタイプ（飲酒習慣・食 の過不足)、(2)飲酒習慣のみあるタイプ、(3)指摘事項 なしの 3 タイプに分けた。タイプ(1)は飲酒習慣に加 え過食または欠食の見られた者とした。過食は摂取 エネルギーの過剩を反映し、久食では食事を摂らな い分、摂取エネルギーは減少するが、間食の増加や 後の過食を招き肥満を招きやすい。

このように食事量や食事のタイミングの問題が ある可能性があるためタイプ(2)の飲酒習慣のみの者 とは別にした。(1)には肥満者 12 人中 5 人が該当した。 そのうち久食は 3 人に見られ、久食の 3 人全員が 20 〜30 歳代の甲板員だった。また欠食の頻度が比較的 多いC、D、Eには間食も見られた。

過食は 2 名に見られ、両者とも陸上でも過食習慣 があった。なお、表 3 に示した乗組員 B は 6 日の記 録だが、連続した 6 日間の記録なので個人の船上習 慣を表していると考え検討に採用している。タイプ (2)は飲酒習慣のみ見られるタイプで 6 人が該当し、5 人が 40〜 50 歳代、不眠傾向も示していた。そのうち 1 名は飲酒量が日本酒 1 合相当以上と多かった。夕 イプ(3は今回の調査では生活習慣上の問題が見られ なかったタイプとした。

\section{5 船員によるシステム評価}

船員に、下船時、システム評価のアンケート（無 記名自記式）を依頼した。回収できたのは 5 人だっ た。このように回収率が低い背景には、そもそも船 と陸上との間では文書の受け渡しが困難という事情 がある。船員は寄港しても町から離れた港に留まる
ことが多い。郵便ポストのある場所まで行って郵送 するか、どちらか出向かなければ受け渡しができな い。今回の評価アンケートは、あらかじめ船内に保 管してもらい、下船時に記入して会社の担当者に渡 してもらうよう要請した。しかし保管、記入、担当 者への連絡等の負担は比較的大きかったと思われ、 結果的に回収率の低さにつながった。また担当者に とっても、下船者を常に把握しアンケートを回収す ることは難しかった。今後はアンケートの電子化も 必要と思われた。

アンケートの結果を以下に示す。計測装置の操作 手順、PC 操作手順、PC の表示の項目では、ほぼ全員 が問題ないと回答した。しかし詳細な質問への回答 を見ると、“ID とパスワードによる個人認証”に関 しては「十分なセキュリティーはあるが、煩雑でス トレスを感じた」の回答が 3 人、“問診票” は「入力 しにくいところがあった」が 1 人、“歩数計の着脱” は「難しかった」が 1 人、“体重・血圧計測定” は「面 倒と感じることがあった」が 1 人、“自分のデータの 確認機能”は「不要」が 2 人と、改善の余地が見ら れた。さらに使いやすいシステム構設計と計測機器 が望まれる。

また、“本システムに参加して、健康への意識が どのように変わったがを尋ねたところ、「今まで以 上に意識するようになった」が 2 人、「変わらない」 が 3 人だった。自由記述では「毎日の診断で健康状 態をある程度知ることができるので、安心感がある」

「体重が一定であることに気付いた」との意見があ つた。

“健康のために実践を始めたことや考えたこと” も自由記述で問うたところ、「定期的に病院で検査」 「軽い運動、減酒、減煙草」「歩行」との回答があっ た。

表 3 肥満者における個別の船上生活習慣記録日数

\begin{tabular}{|c|c|c|c|c|c|c|c|c|c|c|c|c|c|c|c|c|c|c|c|c|c|c|c|c|}
\hline 食·飲酒分類 & \multicolumn{10}{|c|}{ (1) 飲酒習慣·食の過不足タイプ } & \multicolumn{12}{|c|}{ (2) 飲酒習慣タイプ } & \multicolumn{2}{|c|}{ (3)指摘事項なし } \\
\hline 事例 * & $A$ & & $B$ & & $C$ & & $D$ & & $E$ & & $\mathrm{~F}$ & & $G$ & & $\mathrm{H}$ & & I & & $J$ & & $\mathrm{~K}$ & & $L$ & \\
\hline 年齢 ${ }^{* *}$ & 2 & & 1 & & 1 & & 1 & & 1 & & 2 & & 2 & & 2 & & 2 & & 1 & & 2 & & 2 & \\
\hline 総記録日数(日) & 70 & & 6 & & 38 & & 19 & & 28 & & 15 & & 54 & & 43 & & 50 & & 20 & & 23 & & 23 & \\
\hline 飲酒(日) & 68 & $97 \%$ & 6 & $100 \%$ & 35 & $92 \%$ & 9 & $47 \%$ & 25 & $89 \%$ & 14 & $93 \%$ & 53 & $98 \%$ & 42 & $98 \%$ & 41 & $82 \%$ & 13 & $65 \%$ & 23 & $100 \%$ & 0 & \\
\hline 1合より多い(日) & & & & & 2 & & & & 16 & & 6 & & 9 & & 6 & & & & & & & & & \\
\hline 食事(日) & 過食14 & $20 \%$ & 欠食1 & $17 \%$ & 欠食18 & $37 \%$ & 過食6 & $32 \%$ & 欠食13 & $46 \%$ & 0 & & 0 & & 0 & & 0 & & 0 & & 0 & & 0 & \\
\hline 間食(日) & 0 & & 0 & & 5 & $13 \%$ & 4 & $21 \%$ & 3 & $11 \%$ & 1 & $7 \%$ & 0 & & 0 & & 0 & & 0 & & 0 & & 0 & \\
\hline 不眠(日) & 61 & $87 \%$ & 0 & & 1 & $3 \%$ & 4 & $21 \%$ & 25 & $89 \%$ & 8 & $53 \%$ & 36 & $67 \%$ & 36 & $84 \%$ & 48 & $96 \%$ & 1 & $5 \%$ & 22 & $96 \%$ & 6 & $26 \%$ \\
\hline 喫煙(日) & 70 & $100 \%$ & 6 & $100 \%$ & 37 & $97 \%$ & 0 & & 28 & $100 \%$ & 14 & $93 \%$ & 54 & $100 \%$ & 0 & & 0 & & 0 & & 0 & & 23 & $100 \%$ \\
\hline 平均歩数 (歩/日) & 4571 & & 9910 & & 4447 & & 9982 & & 4049 & & 5327 & & 6646 & & 7872 & & 4505 & & 7092 & & 3900 & & 8727 & \\
\hline
\end{tabular}

* A L までの 12 人

**1 は 20〜30 歳代、2 は 40～50 歳代を示す 
さらに、今後の要望について選択肢から選んでも らったところ、「健康情報の測定の簡易化・自動化等 でより意識せず成されること、測定項目を増やすこ と」「必要時のコールセンター (陸上医療機関等) と の T V 電話、音声電話（+静止画通信）でのやりと り」「健康に関する情報提供」「船員専用のW e b サ ーバの設置などのサービスの提供（実測データに基 づく自動診断など)」が挙げられた。

\section{4. 考察}

\section{1 本研究船員の概要}

船員検診のデータと一般検診受診者とを比べる と船員で肥満の割合が多かったとの報告がある ${ }^{(9)}$ 。 今回の結果でも乗組員に肥満は多かった。ただ船員 検診における肥満の割合は 2000 年度 $37.97 \%$ でっ たが本調査では $57.9 \%$ と高く、今回の被験者には肥 満が多かったと言える。活動量の目安となる歩数 ${ }^{(11)}$ は各年代とも全国平均より歩数が少なく、特に 50 歳代で少ない傾向が見られた。船上では通勤がなく 限られた環境のため活動が制限されること、50 歳代 の者のうち 4 人は船長、機関長、甲板長といった管 理職であり、荷役などの作業も少ないことなどが理 由として考えられた。ただ、船員の歩数がこのよう に少ないとは限らない。外航航海中の 2 隻の大学練 習船（649 トン、1886 トン）の船員の平均歩数はそ れぞれ 8395. 5 歩/日、10975.8 歩/日で、船体が大き く階段の段数が多い船では歩数も多かったとの報告 もある ${ }^{(12)}$ 。船上の歩数は空間の大きさや作業の種 類などで変わると思われる。

血圧は測定時刻が人により違ったので随時血圧 として評価したが、最高血圧の平均が $140 \mathrm{mmHg}$ 台の 軽度の高血圧域になった者が 3 人見られ、40～50 歳 代であった。

\section{2 船上と陸上の生活習慣}

本調查で船員の日々の生活習慣記録を得ること ができた。これは船員の自覚的生活習慣の実測とも 言える。しかし調查期間に船員の交代があるため記 録日数に差があり、記録頻度が毎日でない者もいた。 ただ後者に関しては全く記録しない状態にはならず 継続性は保たれていたため、船上の生活習慣をある 程度反映していると考えた。

問診の結果では、記録日の総数に対する過食や欠 食、間食の割合は比較的少なかった。また過食や欠 食、間食が見られた人数もそれぞれ 3 人、 5 人、8 人と多くはなかった。船上の過食は少なかったが、
陸上の生活習慣調査では「毎日」あるいは「週に 1 回以上」過食がある者は 8 人と比較的多かった。船 陸の差は統計的にも有意となり、陸上に比べて船上 では過食が減ることが示された。船上の給食は定食 の形で提供されるため、食事量は概ね一定であり、 過食には繋がりにくいためと考えられた。

欠食 5 人はすべて甲板員であった。当直明けの朝 食時は睡眠時間のためやむを得ず欠食することがあ るという甲板員の意見もあり、勤務時間の理由で欠 食している者も含まれる。欠食者の年代内訳は 20 歳代が 2 人 30 歳代 1 人、 50 歳代 2 人であった。船 陸間比較では欠食は有意な差が見られなかったが、 陸上で欠食習慣のあった 7 人中 4 人が船上で全く欠 食をしていなかった。一般的に欠食は朝食に見られ ることが多いが、船上では給食が用意されるため朝 食を摂取しやすい環境にあるため欠食習慣を断つこ とができた者もいたと思われた。

欠食者が同時に間食をしているか調心゙たところ、 二つが同時に見られるのは欠食日の $12.6 \%$ れった。 したがって間食は必ずしも欠食を補うためとは限ら ない。

船陸比較では陸上の間食習慣は船上でも維持さ れ、間食が全くなくなったのは 1 人だけだった。た だ頻度は陸上より減少する傾向が見られ、船上で毎 日間食する者はいなかった。船上では 3 食規則的に 食事を摂るため頻繁な間食は必要がないと思われた。 以上のように、食事の問題点については勤務の都合 や陸上の生活習慣、個人の嗜好などによる個人差が 比較的大きいと思われ、それらの事情も含めた個別 の助言が必要と思われた。

飲酒に関しては、人数も飲酒をする日数の割合も 共に多かった。特に毎日の飲酒は 10 人（被験者の $52.6 \%)$ であった。40 歳代以上に限定すると 8 人で、 これは 40 歳以上の $72.7 \%$ にたり内航船員の調査の $52.6 \%$ より多かった。船陸比較では船上と陸上の飲酒 習慣は変わらず、常習化が見られた。これは喫煙に も当てはまった

睡眠時間は、陸上については質問紙調査で「普段 の睡眠時間」として尋ねたので日々の変化はわから ない。したがって単純比較はできないが、船上では 4 時間未満が 10 人に認められ減少がうかがわれた。 一方、睡眠時間が 4 時間未満でも熟睡感のある者、 睡眠時間は 6 時間以上で継続していてもほとんど不 眠である者などもいた。

また、不眠の割合は 50 歳代が $66.5 \%$ と多かったが、 船上においてほぼ毎日不眠が見られた 50 歳代の 5 人のうち 3 人は陸上では「ほぼ毎日よく眠れる」と 回答していた。加齢により睡眠を維持する機能は低 
下し、睡眠は浅くなり中途覚醒や早朝覚醒が増加す ることが分かっている ${ }^{(13)}$ 。本調査の 50 歳代の不眠 も、62.3\%が「夜中に目が覚める、あるいは眠れない」 だった。家庭でリラックスしているときは熟睡する ことができても船内では職務から解放されない心理 的負担、摇れや騒音等の環境要因などにより睡眠機 能がより低下寸る可能性がある。

このように陸上と比べ船上で変化する生活習慣 と、船上では変わらない生活習慣があり、船員の健 康管理を行う上では船上と陸上の両方を分けて考え る必要がある。

\section{3 肥満者の船上生活習慣}

肥満の原因としては、食べ過ぎや運動不足 ${ }^{(7)}$ 、遺 伝や環境因子 ${ }^{(14)}$ など多様な要因と、背景としてそれ が蓄積されてきた時間経過がある。現場の保健指導 の中でこれらを正確に把握するのは困難であり、現 在の生活の中で肥満を維持、助長している要因を見 つけ出し、解決可能な方法を本人と共に模索し実行 してもらうように働きかけることが、より有用かつ 有効であると考えられる。船上健康管理の目的は健 康的な生活の支援である。この視点から、本調查で は、肥満者から得られた情報の中、有用であると考 えられる要因について検討を行った。

本調查で肥満者をタイプ(1)〜(3)に分類した。タイ プ(1)と (2)ではともに飲酒習慣がある。飲酒習慣は肥 満者 12 人のうち 11 人に見られ高率であった。過剩 飲酒が、肥満を助長させる可能性があるとの指摘 ${ }^{(15)}$ や、内臓肥満とそれに関連する生活習慣病の蓄積で あるメタボリックシンドロームが関連するとの報告 もある(16)。

本結果では、飲酒量は日本酒 1 合相当など適正飲 酒の範囲内の者も多かったが、1 合より多い者もお り、過剩飲酒の可能性も念頭に置く必要がある。こ れ以上体重を増加させないためにも、アルコールの 種類、量、頻度、さらに飲酒に伴う食事量（または つまみ）の確認とアドバイスが必要である。

飲酒習慣に加えて食の過不足があるのがタイプ (1)である。過不足の原因と対策についてのアドバイ スが必要である。特に欠食は当直など勤務の都合に よることもある。勤務形態についても情報収集を行 い、食事が摂れない場合はどのような食品を摂った らよいか等、具体的に伝える必要がある。

今回の調查で生活習慣上の問題が見られなかっ たのがタイプ(3である。このタイプについては今回
の問診では得られなかった問題も探る必要がある。 本来、食事調査でエネルギー摂取量を調べるために は、主食の量や間食の種類、量に関しての調査が必 要だが、本調査の問診では協力者の負担を極力減ら すために調査項目を必要最小限に留めたため、詳し い食事内容やエネルギー摂取量はわからない。たと えば食事量についても協力者の主観に基づいて多い か少ないかを答えてもらう形式としたため、食の過 不足の自覚が無い場合等は問題が検出されない可能 性もあると思われた。

対策として食事の写真をデジタルカメラで撮っ て船内の専用 $\mathrm{PC}$ に入れる、調理担当者があらかじめ 献立を作成し船内の専用 PC に記録するなどの方法 も考えられる。しかしながら、調理担当者の理解が 必要となること、また健康管理としては、船員自身 の摂取量の自己コントロール能力を高める方が有効 ではないかと考えられることなどから、システムに 組み入れることはその是非を含めて検討する必要が ある。今後の課題は、主食や間食のエネルギー摂取 量を推測できるような問診項目の設定や、期間ごと に問診のテーマを変えるなどの工夫で、少数の問診 項目でもより具体的で有用な情報を得られるように 寸ることである。このような改良によって、タイプ (1)、(2)に対しても問題点をより明らかにすることが できる可能性がある。

今回のシステムでは、問診による詳細な食事調查 は行わなかったが、体重や BMI のモニタリングと評 価を行うことによって、船員各人のエネルギー量の 過不足を知る指標を得ることはできた。

厚生労働省策定の日本人の食事摂取基準 2010 活 用の基礎理論によれば (17)、「エネルギー摂取量につ いては、体重ならびに体格指数 (body mass index : BMI）などが比較的容易かつ正確に測定でき、エネル ギー収支のバランスを評価できるため、食事調査に よって得られるエネルギー摂取量に代えて、これら の指標を用いるほうがエネルギー摂取量の評価には 好ましいと考えられる」とされている。これは、自 己申告による食事調查では、エネルギー摂取量が過 小評価されやすく、エネルギー摂取量の日間変動も 考慮されにくいからである。

本システムでは日々の食事内容を調查すること で日間変動を考慮したデータを得ることはできると 思われるが、エネルギー収支のバランスを知る上で、 問診による把握は正確とは言えない。船上健康管理 では、習慣的な体重計測によってエネルギー摂取量 
が過剩か不足かを自覚してもらい、問診を手掛かり に各船員にあった食生活を提案し、後述のような食 事の自己調節を促寸という方法がいいのではないだ ろうか。

一般に船上給食は船員法の食料表に基づき、使用 する食材の量、すなわち 10 日間の可食量が 6 類 ( 第 1 類: 魚介類、獣肉類、卵類、豆類等、第 2 類: 乳類、 骨ごと食べられる魚等、第 3 類: 緑黄色野菜類、第 4 類 : その他の野菜類、果実類等、第 5 類 : 殼類、 砂糖類、いも類等、第 6 類 : 油脂類。）ごとに定めら れている。1980 年代の外航船における調查 ${ }^{(18)}$ にお いて、食料表に基づく船内の食事のエネルギー量は 一日当たり $3057 \mathrm{kcal}$ と算出されている ${ }^{(19)}$ 。食料表 は 1997 年に改訂されたため過去のエネルギー計算 が現状に当てはまるとは限らないが、船員によって は給食全量摂取がエネルギー過剩となっている可能 性はある。

実際に本調査の対象者について、個別に一日当た りの推定エネルギー必要量 ${ }^{1}$ (当該年齢、性別、身長、 体重、及び健康な状態を損なわない身体活動量を有 する人において、エネルギー出納が 0 となる確率が もっとも高くなると推定される、習慣的なエネルギ 一摂取量の 1 日当たりの平均值）を身体活動レベル


$3536 \mathrm{kcal}$ と幅が見られた。活動量は運航形態や職種 によって変動し、エネルギー摂取量は日間変動があ るので、数日から数週を平均すればエネルギー収支 のアンバランスは相殺される可能性もあるが、歩数 の記録を見ると歩数の多い少ないは習慣的と見られ る傾向にあり、エネルギー量の過不足が日常化して いる可能性も考えられた。

また、食料表の備考には「毎日の食事には 6 類を 適宜組み合わせ、 10 日間を通じて 1 日当たりの総熱 量を下まわらないよう合理的に配分すること」と記 載があり、食材の規定はあるものの、食材の配分や 調理法は厨房による裁量部分が大きいと推測される。 とはいうものの厨房で一人一人の船員の推定エネル ギー必要量に合わせ食事を調整することは不可能で あり、提供する食事を調整するのは限界がある。船 員各自が自分で食事量を調整し、運動を取り入れ、

1 推定エネルギー必要量（kcal/日）=基礎代謝基準 值 $(\mathrm{kcal} / \mathrm{kg}$ 体重/日） $\times$ 基準体重（kg）×身体活動 レベル，身体活動レベルは I 〜IIIの 3 段階で示し、 值は次の代表值を用いる。I（低い）：1.5，II （ふ つう) : 1.75 , III (高い) $: 2.0^{(20)}$
体重管理を行うことが、やせや肥満の予防に重要で ある。具体的には、エネルギーが過剩な場合は「食 事を残す」「活動量を増やす」、不足する場合は「お かわりをする」「間食をとる」など自己で調節する必 要があると考える。

その他の生活習慣では、歩数の少なさ、睡眠の質 の低さが有用なデータとなる。船上では運動量は限 られる。安全な範囲で体を動かすことを推奨しなが ら、上陸する機会や下船中に運動することが望まし い。事実、陸上でも運動を習慣化していたのは一人 もいなかった。船上では歩数にて活動量の目安を示 しながら、陸上で運動の意識を高めることが対策と して考えられる。また睡眠不足は肥満を助長すると の報告もある ${ }^{(21)}$ 。睡眠の改善や意識的に休養をと るなどの指導も可能であろう。

\section{5. まとめ}

1. 船員の健康情報を、船陸間通信を利用して収集 し陸上に蓄積する船舶遠隔健康管理システムを 開発、内航船に実搭載し乗組員の日々の健康情 報をモニターした。

2. 生活習慣に、船上と陸上で変化するものと継続 するものがあった。船員の健康管理では両者を 考慮する必要があると考えられた。

3. 食事は規則的で、陸上より食べ過ぎ（過食）は 減少した。一方、久食、間食の習慣は変わらな かった。

4. 肥満者の検討では飲酒習慣が多く見られ、飲酒 が指導の導入になると考えられた。食の過不足、 欠食、活動量 (歩数)、睡眠などの問題を持つ者 も認められ、個別の対応が必要と考えられた。

\section{謝辞}

ご協力いただいた船舶乗組員の皆様と宇部興産 海運株式会社に深く感謝申し上げる。東邦大学の小 林未果先生、日本郵政株式会社の伊野宮興志先生に ご助言頂いた。また菱洋エレクトロ株式会社には技 術的サポートを頂いた。本研究は東京海洋大学海洋 工学部研究プロジェクトの一部之 JSPS 科研費 24650420 の助成を受けたものである。

\section{参考文献}

（1）国土交通省海事局運航労務課：最新船員法及び 関係法令,pp.63-64,成山堂書店,2007.10.

（2）神田寛・村山義夫 : 海で働く人の健康と体力づ 


\section{日本航海学会論文集 第129巻 第128回講演会にて講演}

<り, p.3, 成山堂書店, 1997.

（3）真辺春蔵 - 難波精一郎 - 吉田光雄 - 吉川敏枝 黒田隆・松木哲：船舶乗組員の船内行動，人間 工学, Vol. 5, No. 5, pp. 315-322, 1964.

(4) 加藤和彦: 船員の船内生活と健康, 日本航海学 会論文集，No. 114，pp. 209-215， 2006.

（5）福田直子・庄司るり・亀山こころ・芦田研二： 船上の健康管理を目的とした遠隔医療の実験, 日本航海学会論文集, No. 125, pp. 241-247, 2011.

（6） e-Stat (政府統計の総合空口）：国民健康栄養調 査, 2011 年,

http://www. e-stat. go. jp/SG1/estat/GL080201 01. do?_toGL08020101_\&tstatCode $=00000104174$ 4\&requestSender=dsearch, 2013. 7 .

（7）和田高士 - 福元耕 - 常喜真理 - 吉澤祥子 - 中崎 薰・橋本博子・栗栖敦子・浦島充佳・池田義雄 : 肥満者の生活状況:22 の生活要因による解析, 肥満研究 (日本肥満学会志), 10 (3), pp. 282-286, 2004.

（8）厚生労働省：健康日本 21 (アルコール), http://www1. mhlw. go.jp/topics/kenko21_11/b 5. html\#A52, 2013. 7.

（9）高橋光長：船員検診データの検討資料- II , 海上 医学研究 39-1, p. 35, 財団法人船員保会, 2002

(10) Hoeyer JL and Hansen HL :Obesity among Danish seafarers, Intrnat. Marit. Health, 56, pp.1-4, 2005.

(11) Tudor-Locke C, Williams JE, Reis JP and Pluto D: Utility of pedometers for assessing physical activity: convergent validity. Sports Med, 32(12), pp. 795-808, 2001.

(12) 阿保純一 - 小池義夫 - 野田明 - 林敏史 - 濱田浩 明・山崎紗衣子・峰雄二・喜多澤彰・萩田隆一・ 内田圭一・村松園江 : 長期航海船舶乗組員の骨 量変化, 東京水産大学論集, 39, pp. 25-33, 2003.

(13) Kim K, Uchiyama M, Okawa M, Liu X and Ogihara R : An Epidemiological Study of Insomnia Among the Japanese General Population, Sleep, 23 (1), pp. 1-7, 2000.

(14) Keith SW, Redden DT, Katzmarzyk PT, Boggiano MM, Hanlon EC, Benca RM, Ruden D, Pietrobelli A, Barger JL, Fontaine KR, Wang C, Aronne LJ, Wright SM, Baskin M, Dhurandhar NV, Lijoi MC, Grilo CM, DeLuca M, Westfall A0 and Allison
DB : Putative contributors to the secular increase in obesity: exploring the roads less traveled, Int J Obes, 30(11), pp. 1585-1594, 2006.

(15) Tolstrup JS, Heitmann BL, T jonneland AM, Overvad OK, Sorensen TI and Gronbaek MN: The relation between drinking pattern and body mass index and waist and hip circumference, Int J Obes, 29, pp. 490-497, 2005.

(16) 大塚俊昭 - 川田智之 - 矢内美雪 - 北川裕子 ・菅 裕彦：一職域男性集団におけるメタボリックシ ンドロームの発症率およびメタボリックシンド ローム発症に関連する生活習慣因子の検討, 産 衛誌，53, pp. 78-86, 2011.

（17）厚生労働省: 日本人の食事摂取基準 (2010 年版), I 総論 (策定理論、活用理論)「活用の基礎理論」, http://www. mhlw. go. jp/shingi/2009/05/s0529 -4. html, 2013. 9.

（18）豊瀬恵美子：船内食事実態についての考察，海 上医学研究, 19(1), pp. 129-140, 1982.

（19）豊瀬恵美子：商船の栄養管理（III）－食事の実 態一, 海上医学研究, 19 (1), pp. 117-128, 1982.

（20）厚生労働省: 日本人の食事摂取基準 (2010 年版), II 各論 1. エネルギー, http://www. mhlw. go. jp/shingi/2009/05/dl/s0 529-4e. pdf, 2013. 9.

(21) Chaput JP, Despres JP, Bouchard C and Tremblay A: Longer sleep duration associated with lower adiposity gain in adult short sleepers, Int J Obes, 36, pp. 752-756, 2012. (doi:10. 1038/ij. 2011.110). 